\title{
O SANTO OFÍCIO NA MODERNIDADE E O PROCESSO INQUISITORIAL
}

ALINE SUELI DE SALLES SANTOS 


\title{
O SANTO OFÍCIO NA MODERNIDADE E O PROCESSO INQUISITORIAL
}

\author{
Aline Sueli de Salles Santos ${ }^{1}$
}

\section{RESUMO}

A Inquisição foi criada pela Igreja Católica em meados da Baixa I dade Média Na Península I bérica foi uma instituição especial mente pujante entre os séculos XIV e XVII. A associação dos Monarcas Absolutistas português e espanhol com a Igreja Católica Romana obedeceu mai sainteresses políticoseeconômi cos do quepropriamente religiosos, ou seja, buscava servir à consolidação e manutenção dos modernos Estados-nação. Nessa ligação ambas as instituições eram beneficiadas, legitimando-se socialmente, protegendo-se e atacando o inimigo, financiando-se. Nesse contexto, o processo inquisitorial, procedimento criado pela Igreja para instrumentalizar sua ofensiva contra os "hereges", foi peça primordial para a eficácia dessa parceria. É apenas dentro desse contexto que se é possível entender a pseudorracional idade de seu funcionamento e o papel desempenhado pelo Direito Processual na consolidação nacional ibérica.

Palavras-chave Inquisição Moderna Estados-nação ibéricos. Processo inquisitorial.

\section{RESUMEN}

La Inquisición fue establecida por la Iglesia Católica a mediados de la Baja Edad Media. En la Península Ibérica era una importante instituición, especialmente entre los siglos XIV y XVII. La asociación de los monarcas absolutos portugués y español con la Iglesia Católica de Roma obedecía más a intereses políticos y económicos que a religiosos, o sea, buscó servir a la consolidación y mantenimiento de los modernos Estados-nación. En esta relación las dos instituciones fueron beneficiadas con legitimación social,

1 Graduada em Direito pela USP, especialista em Direito Administrativo pelo IDP, mestre em Direito pela UNISINOS, doutoranda em Direito pela UnB e professora da UFT. Email: alinesalles@uft.edu.br. 
protección y financiamiento mutuos, y ataque a sus enemigos. Así, el proceso inquisitorial, procedimiento establ ecido por la I glesia para instrumentalizar su ofensiva contra los "herejes", fue primordial para la eficacia de esta asociación. Y es tan solo en este contexto que se puedeentender a la pseudo- racionalidad de su funcionamiento y el rol del derecho procesal en la consolidación nacional ibérica.

Palabras dave Inquisición Moderna. Estados-nación ibéricos. Proceso inquisitorial.

\section{IINTRODUÇÃO}

O advento da Modemidade rompe em muitos aspectos com o Medievo. Dentre essas mudanças, uma das mais significativas foi a centralização do poder político, com a formação dos Estados-nação modernos. No entanto, a I nquisi ção será uma institui ção que atravessará os tempos e só será extinta, oficialmente, no séc. XIX, no início da Idade Contemporânea.

É certo que a I nquisição Medieval é, em muitos pontos, diferente da Moderna, mas uma faceta importante foi mantida, e talvez esteja aí seu maior legado: o processo inquisitorial. Revestido de princípios racionaisquetransformaramo panorama do direito processual, foi um instrumento fundamental para que a Santa I nquisição perseguisse seus objetivos.

Enquanto a Inquisição Medieval era uma empreitada basicamente religiosa, feita pela Igreja para punir aqueles que contestassem ou não seguissem seus dogmas, posteriomente ela se ajusta a uma nova realidade marcada pela ruptura da 
hegemonia católica na Europa (com a Reforma Protestante), e a I nquisição Moderna só poderá acontecer com a união entre os Estados modernos e a I greja Católica Romana. Isso servia e era necessário aos recém-criados estados português e espanhol que estavam em processo de formação e consolidação.

Sabese que a união do poder político centralizado e superior aos demais poderes, juntamente como estabelecimento de uma cultura única (que tivesse o condão de promover coesão e solidariedade social) é o cerne da formação dos Estados modernos. Alertanos Habermas (1995, p. 87-90) que "os dois componentes do conceito de Estado-nação - Estado e nação referem-sea processos históricos convergentes, porém distintos: a formação dos Estados modemos e a construção das nações modernas." A Inquisição passa, então, a ser administrada pelos países ibéricos, sendo utilizada para atingir seus objetivos de manutenção do poder político e consolidação de um projeto nacional.

Através de uma análise bibliográfica sobre a formação e trajetória da Inquisição portuguesa e espanhola na Idade Modema, analisam-se as etapas do processo inquisitorial buscando compreender a relação dos princípios legais que o orientam com a formação daqueles Estados modernos e absolutistas. 


\section{A INSTAURAÇÃO DA INQUISIÇÃO MODERNA NA PENÍNSULA IBÉRICA}

A Inquisição surge em 1232 comos editos do imperador Frederico II que ordenou a persegui ção dos hereges do Sacro Império Romano Germano. O papa Gregónio IX assumea tarefa e para cumpri-la nomeia inquisidores entre os freis dominicanos visando proteger a fé católica (BOFF, 1993, p. 13).

Na inquisição medieval, a Igreja age com autonomia. Na Península I bérica existiam três grandes comunidades que conviveram pacificamente durante séculos: a comunidade cristã, a muçul mana ea judia.

Essa coexistência de respeito mútuo deu a Portugal e Espanha uma característica de tolerância muito diferente das outras nações. Sinal dessa real idade é que a determinação saída do IV Concílio de Latrão, em 1215, detodos os judeus usaremo distintivo para se diferenciarem dos cristãos não foi segui da nem em Portugal nem na Espanha (NOVINSKY, 1983, p. 23).

Ao longo do século XIV começam a aumentar na península, pouco a pouco, os pedidos de restrições às liberdades dos judeus. Estes já eram tradicionalmente comerciantes, burgueses, e com o avanço do comércio, a expansão marítima, começa a surgir uma classe media cristã, até então quase inexistente, cujos interesses se chocam com os da burguesia judaica. Essa nova classeemascensão tem como grandeal iadaa I greja que faz uma grande propaganda antijudaica, cul pando os judeus por todos os males da humanidade. 
Foi na Espanha, no entanto, que primeiramente essa onda de intolerância levou ao estabel ecimento da I nquisição.

\section{0 contexto histórico da inquisição espanhola}

Com a explosão de manifestações contra os judeus na Espanha, ocorre um fenômeno único na história judaica, o batismo vol untário emmassa, pois nunca os judeus tinhamagi do assim; ante opção do batismo ou morte, a maioria preferia a morte, pois considerava o catolicismo uma idolatria. Batizados, garantiam os mesmos direitos dos cristãos, pois as restrições dos Concílios não tinham efeitos sobre eles. Isso levou a sociedade espanhola a conviver com três grupos distintos de origem judaica: os que continuaram ligados à fé judaica, os que se converteram mas continuavam segui ndo seus costumes judai cos secretamente, e aqueles que, convertidos, passaram a ser leais católicos (NOVINSKY, 1983, p. 25-26).

No século XV, a Espanha passou por várias crises (políticas, econômicas, peste, guerras). Aomesmo tempo, muitos "cristãos-novos" foram assimilados à al ta sociedade, através de casamentos e de al tos cargos públicos. Como meio de desviar a atenção da crise, os donos do poder voltaram-se então para os conversos, acusando-os de usurparem os mel hores cargos na sociedade, que deviam pertencer aos cristãos.

Tem início, então, uma política racista, que acusa os cristãos novos defalsi dade, mas que na verdade éa luta "entrea burguesia cristã-velha ea burguesia cristãnova, sendo, portanto,

Revista Esmat, Palmas, Ano 4, o 4, pag. 9 a 38 - jar/dez 2012 
um fenômeno da cidade, burguês" (NOVISNKY, 1983, p. 29).

Deu-se origem, então, aos "estatutos de pureza de sangue", segundo o qual os descentes de judeu ou mouro até a sétima geração não podiam pertencer às instituições que o adotassem. A I grejafoi umadasúl timas aseutilizar dos estatutos, o que mostra que o problema era social, apesar de ser justificado religiosamente. Essa política racista também foi adotada nas colôni as eno Novo Mundo, sendo estendida tambémaos negros, índios eciganos.

A propaganda da Igreja aumenta mais e mais, e é acompanhada de um confronto cada vez mais acentuado entrea burguesia cristã, que está aumentando, ea burguesia conversa.

Em 1474, sobem ao trono Fernando e Isabel, unificando o reino deAragão eCastela e dando origemao Estado espanhol. Visando a sua consolidação, em troca do apoio da Igreja e da burguesia cristã, introduzem maiores medidas restritivas contra judeus e conversos. O objetivo dos monarcas era lograr a expul são dos mouros de Granada e extirpar a heresia judaica e conversa, para o que os cofres reais não dispunham de meios. A solução encontrada foi negociar coma I greja o estabel ecimento do Tribunal da Inquisição, pois os bens consegui dos através dos confiscos poderiam ser utilizados para tanto. A Inquisição surgiu como al temativa para encher os cofres do Tesouro.

Mesmo duvidando das intenções puramente religiosas dos reis, em 1478, por razões políticas, o papa Xisto IV autoriza o Tribunal da Inquisição em Castela. Na Inquisição Moderna, a Igreja só autoriza seu estabelecimento, pois quem a idealiza 
é o rè, para resolver um problema social, e não religioso como aparenta. Essa inquisição superou em muito a Inquisição Medieval, em crueldade e intensidade, chegando também às colônias e só sendo oficialmente extinta em Portugal em 1821 e na Espanha em 1834.

Com a expulsão dos mouros de Granada, em 1492 (mesmo ano da conquista da América), a bandeira da unificação nacional faz-se mais forte e decreta-se a expul são dos judeus e mouros. A eles é dada uma opção: o batismo. Isso correspondeà ideia de que a um Estado passa a corresponder o desejo de uma única nação e, consequentemente, a necessidade de pôr fim à diversi dade cultural e religiosa.

Devido a problemas deemigração, a maioria dos mouros se converteu, ainda que continuassem a praticar sua religião secretamente. Por serem mais pobres econstituírem boa parteda mão deobra do país, éprovável queincomodassemmenosqueos descendentes de judeus, que detinhammai or poder econômico e ocupavam cargos de prestígio. Já em rel ação aos judeus, muitos saíram da Espanha e suas fortunas foram revertidas para o Tesouro Real.

Grande parte dos imigrantes judeus foi para Portugal, quecobrava uma propi na por cabeça. Foi essa leva migratória de judeus a Portugal o estopim para a instauração do Santo Ofício também naquele país. 


\subsection{Santo Ofício em Portugal}

Assim como sua vizinha, a Espanha, também Portugal tinha tradição de tolerância entre as populações de diferentes credos. Durante toda a Inquisição Medieval, mouros e judeus gozavam de proteção em território português, podendo praticar livrementeseus credos eviver conformeseus costumeseleis, sob a liderança de seus respectivos chefes políticos (NOGUEIRA, 2000).

No entanto, a partir do século XIII, a Igreja começa a pressionar Portugal para uma instituição mais efetiva da Inquisição. Soma-se a isso insatisfações sociais cada vez maiores entre os três grupos, em especial entre cristãos e judeus. Com a grande entrada de judeus expul sos da Espanha, a fatia dessa população, que já era alta, ficou ainda maior e, consequentemente, os conflitos se agravaram.

Soma-sea isso o fato de a economia portuguesa estar em frangal hos, apesar da extensão territorial do Império, uma vez que "toda a riqueza do Oriente passava apenas por Portugal, e ia fomentar o trabal ho estrangeiro, que nos fornecia de todas as coisas." (SÉRGIO, 1977, p. 96).

Em 1496, o ré português segue o exemplo dos rés católi cos espanhóis, e decreta a expul são dos judeus. No entanto, ao dar-secontados prejuízos queo jáesfaceladoEstado português sofreria, resolve seu problema através de um episódio que ficou conhecido como "batismo forçado" (NOVINSKY, 1983, p. 34). Isto ocorre numa cidade portuária quando grande massa de

Revista Esmat, Palmas, Ano 4, no 4, pag. 9 a 38 - jar/dez 2012 
judeus estava pronta a deixar Portugal coma autorização do Rei foi impedida de sair e batizada compulsoriamente (não havia alternativa, uma vez que meios de transporte marítimo foram recusados eera impossível sai r pela Espanha). Origina-se, então, a era dos cristãos-novos, fornecendo uma boa justificativa para a instauração da Inquisição em Portugal.

Depois de cinco anos tentando, finalmente em 1536 D. J oão III, rei de Portugal, consegue a permissão papal para instauração da Inquisição em Portugal, sob seu comando. Essa autorização do papa foi comprada, no começo com al gumas limitações, mas que sumiram com o passar do tempo (NOVINSKY, 1983, p. 36).

Afinal, na virada do Medievo para a Modernidade, ser e viver como cristão não era apenas um problema religioso, mas sim político. E tanto em Portugal, como na Espanha, a Inquisição esteve ligada à centralização do poder e a uma política de unificação nacional, e, nesse caso, o desrespeito aos dogmas católicos agredia não só a I greja como tambémo Estado, representado pel os "senhores cristãos" (LOPES, 2000, p. 107).

Assim, a Inquisição reveste-se de uma "auréola" religiosa para esconder os verdadeiros motivos sociais que a necessitavam. Dentre esses motivos, não se pode perder de vista a questão do confisco dos bens que a Inquisição propiciava, tão necessários à manutenção do Estado português.

Este, certamente, é um dos fatores que justificam a divisão do poder juń́dico coma I greja, nesses estados. 


\subsection{Os estados modernos e o Tribunal da Inquisição}

O surgimento do Estado Moderno, na Europa a partir do século XV, veio com as características básicas da existência de uma unidade territorial dotada de um poder político soberano (centralizado e superior aos demais), respondendo a uma necessidade de ordem e autoridade, gerada por uma nova distribui ção da propriedade, naquele momento histórico.

A Nação aparece, nestecenário, como "uma comuni dade política imaginada - e imaginada como implicitamente limitada e soberana" (ANDERSON, 1989, p. 14), resgatada ou criada artificialmente, como um símbolo unificador, onde o Estado poderia“" legislarafavor dal eal dadeedeterminaranteci padamente os resultados da livre escol ha. As raízes postuladas poderiam ganhar existência pela legislação e seriam cuidadas pelos órgãos estatais da lei e da ordem." (BAUMAN, 1998, p. 236).

Interessa ressaltar que essa instituição vai buscar monopolizar a dimensão jurídica, extinguindo, lentamente, "toda e qualquer forma de pluralismo social e jurídico", fazendo com que a história das monarquias modemas seja a história de uma cada vez mais intensa tomada de consciência por parte do Príncipe, da sua cada vez mais precisa percepção da essencialidade do direito no âmbito do projeto estatal, da exigência sempre maior de propor-se como legislador. Melhor, de conceber na produção de normas autoritárias o emblema e o vigor da real eza e da soberania, em oposição ao ideal medial, que via o Príncipe, sobretudo, como juiz, juiz supremo, o grande 
justiceiro de seu povo (GROSSI, 2004, p. 40-41).

Essa diretiva não foi plenamente assumida por Portugal, cujo poder juńdico manteve-se de certa forma dividido com a Igreja, por meio da manutenção de um direito próprio e autônomo para disciplina eclesiástica, o di reito canônico, que se constitui “não apenas uma fonte importantíssima de regulação autônoma da comunidade dos fiéis no domínio espiritual, como um instrumento da Igreja militante para a tutela do governo temporal do mundo." (HESPANHA, 2006, p. 206). Essa autonomia do direito canônico, no entanto, não era ilimitada, já o corpo clerical submetia-se às normas civis estabelecidas para o bem-comum, cabendo ao Estado, em casos limitados, exercer o poder sobre aquele.

O respeito ao direito canônico incluía a aceitação deuma jurisdi ção eclesiástica(paralelaàjurisdição estatal , propriamente dita) que atingia também os leigos, inclusive em matérias civis. Além da competência contenciosa reservada, a Igreja ainda exercia uma jurisdição voluntária para quem quisesse se submeter a seus tribunais eclesiásticos. O Tribunal do Santo Ofício da Inquisição era um dos ramos da jurisdição ecl esiástica especial, detendo competência exclusiva em matérias de heresia, apostasia, blasfêmia, sacrilégio e certos crimes sexuais (HESPANHA, 2006, p. 208-214).

Mesmo com um rol de competências relativamente reduzido, é inegável a força simbólica e o poder cultural que ele exerce para a disciplina do povo, ainda mais quando este Tribunal usa de procedimento próprio, criado ainda na Idade 
Média, que, apesar de sua proposta "racional ista", será até hoje exemplo depersuasão ecruel dade Vejamosa seguir os caminhos processuais da "cristianíssima e santa inquisição".

\section{PROCESSO INQUISITORIAL}

Ao contrário do que parece indicar hoje o senso comum, que relaciona a Inquisição com bruxas queimando na fogueira, o processo inquisitorial tinha como premissa básica a racional idade. Representou a superação do modelo acusatório que responsabilizava o acusador, cuja decisão era dada por um juiz imparcial, já que fruto da intervenção divina através dos ordálios² ou dos duelos (NASPOLINI, 2005, p. 192-193). No decorrer da Baixa Idade Média, esse tipo de processo já não conseguia dar respostas adequadas às necessidades da Igreja, pois dificultava o julgamento e a condenação dos hereges que ameaçavam seu poder.

A partir do séc. XIII, a Igreja proíbe a participação do clero nos ordálios, instituindo novo sistema racional de provas, baseado num princípio aritmético que impunha padrões rigorosos para sua valoração (provas plenas, semiplenas e indícios longínquos) (NASPOLINI, 2005, p. 195).

J untamente, destitui a responsabilidade do acusador pela denúncia e prevê a possi bilidade de qual quer pessoa apresentar

2 Os ordálios (ou, as ordálias) eram um tipo de prova não-racional, que dependia da intervenção divina para indicar a culpa ou não do acusado. Como exemplo podemos citar: mergulhar o braço em água fervente, ou carregar ferro em brasa, e os ferimentos serem milagrosamente curados por Deus. 
denúncia, inclusive o próprio Tribunal. Esse Tribunal, por sua vez, também institui uma organização das etapas processuais e impõeo princípio da escrita. A partir de então, estava preparado o sistema para que o juiz deixasse de ser mero árbitro imparcial e passasse a ser um investigador do crime, ao mesmo tempo em que se responsabilizava pela determinação da cul pabil lidade do réu. Percebese que as normas processuais foram feitas não com o intuito de buscar a verdade, mas de atingir certos resultados.

Esse processo, chamado inquisitorial, era previsto de forma escrita nos Regimentos da Inquisição, em especial o Manual dos Inquisidores, redigido em 1376 por um dominicano, Nicolau Eymerich, revisto, atualizado e ampliado já durante a Inquisição moderna (1585) por Francisco de La Peña, outro dominicano. (BOFF, 1993, p. 14).

Depois de expor cuidadosamente sobre os conceitos e tipos de herege e heresia, o Manual passa a disciplinar a prática inquisitorial passo a passo.

Pode-se dividir em duas partes o processo inquisitoral : a primeira, o interrogatório para queo réu confessasse suas cul pas, ea segunda, o jul gamento, na qual o réu se "defendia" por meio das contraditas das acusações feitas através do libelo, que se baseava nas denúncias. Tanto a primeira como a segunda fases eram secretas, e a sentença era votada na mesa da inquisição (SARAIVA, 1985, p. 77). 


\subsection{Denúncias}

Através do Edital da Fé, publicado anualmente, a Inquisição, num serão geral, chamava os fiéis a denunciar tudo o que sabiam ou ouviram, sob pena deexcomunhão, sobre al guém batizado. É importante lembrar que o Santo Ofício era um tribunal cristão e, portanto, original mente só poderia jul gar os batizados, regra que comportava exceções na defesa da I greja.

Nesse mesmo edital, abria-se prazo para o "Tempo do perdão", onde os cristãos deveriam confessar suas culpas completa, espontânea e voluntariamente, a fim de escapar das investigações do Santo Ofício (EYMERICH, 1993, p. 100).

As denúncias, junto com as confissões judiciais, são a base do processo do Santo Ofício, e quem não delatasse o que sabia, além da excomunhão, era perseguido pela Inquisição se descoberto. As denúncias valiam indulgências, inclusive (EYMERICH, 1993, p. 100).

Todas as denúncias eram recebidas, quem quer que fosse o denunciante. Mesmo às dos escravos, excomungados, pessoas de quem não se aceitaria a denúncia no di reito comum, e até cartas anônimas. Um importante tipo de testemunha era os carcereiros da prisão, que supervisionavam o que os presos comiam equando.

Na verdade, o crédi to ou não da denúncia dependia apenas do arbítrio dos inquisidores. Se o denunciante se retratasse, a mesa da Inquisição julgava se anulava ou não o testemunho. Se quisesse, poderia manter a acusação. Qual quer tentativa de 
retirada da denúncia era difícil, mas a facilidade de denunciar era enorme.

Tendo as denúncias, o denunciante indicava outras testemunhas. Com mais de uma testemunha, a prisão já poderia ser efetuada com um mandado escrito. Essas formal idades nem sempre eram cumpridas (SARAIVA, 1985, p. 81).

Com a prisão acontecia o sequestro dos bens do denunciado. O Santo Ofício imediatamente fechava sua casa, impedindo a entrada de outras pessoas que não funcionários da Inquisição. Ou seja, uma família podia ser afastada de sua casa sem culpa própria ou prova da culpa do acusado (NOVINSKY, 1983, p. 58).

\subsection{Interrogatório}

Depois da denúncia, o réu era capturado e levado à mesa do Santo Ofício. Lá, depois de despojado de seus objetos preciosos, ele era instal ado a "desencarregar a sua consciência" (SARAIVA, 1985, p. 81). A ele não era dito o motivo da sua prisão para que o réu declarasse suas cul pas espontaneamente.

Os interrogatórios previstos no Regi mento da I nquisição eram de três tipos: a sessão de genealogia, a sessão na general idade e a sessão na especial idade (SARAIVA, 1985, p. 82). Nos interrogatórios, os réus deviam ser colocados de forma a se constranger diante do inquisi dor que develembrálo sempre de que se mostrará misericordioso se el e confessar com clareza e rapidez (EYMERICH, 1993, p. 114). 
A primeira sessão cuidava da biografia do réu, sua identificação, perguntas sobre sua religiosidade, seus hábitos, seus estudos, suas viagens. Era perguntado tambémsesuspeitava o porquê de sua prisão, sem I he declarar as cul pas que Ihe eram imputadas.

Depois de um mês na prisão, acontecia a sessão na general idade, isto é, não di retamente relacionada aos fatos que constavam na denúncia. Nessa sessão, o réu era indagado sobre os ritos e crenças da seita que era acusado de proferir.

Finalmente a terceira sessão tratava dos assuntos constantes na denúncia, de modo bem abstrato, de modo a não ser possível a identificação do fato a ele imputado ou nem de nenhuma testemunha. Tantas perguntas se fariam quantas fossem as testemunhas, e não quantos fossem os crimes a ele imputados. No caso de poucas testemunhas, o Regimento dizia ser possível multiplicar as perguntas, dividindo os testemunhos. Esse dispositivo destinava claramente a induzir o réu em erro (SARAIVA, 1985, p. 85).

Para impedir o forjamento de confissões, "o uso de perguntasqueinduzissemadeterminadas respostas, demodo que o réu jásoubesse deantemão o queo interrogador desejava ouvir, era proi bido" (LEVACK, 1988, p. 75), conforme se vêno tópico 18 do Manual, "Como interrogar o acusado" (EYMERICH, 1993, p. 114). Ao fim de cada sessão de interrogatório, era feita ao preso uma admoestação para que ele confessasse todas suas culpas.

As confissões eram estimuladas como o único modo de 
obter amisericórdia do Santo Ofício, dependendo essado número de denúncia de terceiros que a acompanhasse(SARAIVA, 1985, p. 85). O réu teria deconfessar tudo, eo Tribunal poderiaordenar que ele confessasse quantas vezes el es achassem necessário para convencimento dos inquisidores, sempre insinuando saberem mais coisas sobre ele, para assim confundir o réu. Se a confissão fosse considerada incompleta, o réu era considerado di minuto e então passaria por mais sessões de interrogatório. Depois disso vinha o libelo do Promotor.

O próprio Manual previa os 10 truques do herege para responder sem confessar e logo em seguida os 10 truques do inquisidor para neutralizar os truques dos hereges (EYMERICH, 1993, p. 119-127).

\subsection{Tortura}

Os interrogatórios eramacompanhados detormentos. “ $\mathrm{O}$ uso da torturajudicial baseia no pressuposto de que uma pessoa, quando submetida ao sofrimento físico durante o interrogatório, acaba por confessar a verdade" (LEVACK, 1988, p. 73). Os réus a que se submetiam os tormentos eram aqueles sobre os quais não havia provas e os diminutos, mas apesar deter que ser aprovada sua utilização por um tribunal, seu uso passou a ser totalmente indiscriminado.

Antes do tormento, o acusado era admoestado a confessar suas culpas. Depois, era examinado por um médico que atestava seu estado de saúde, instado a assinar um documento 
declarando que se algo acontecesse com ele "a cul pa não era dos inqui sidores, mas dele própria, por ter-se mantido pertinaz e escondido o nome dos cúmplices" (NOVINSKY, 1983, p. 61).

A denúncia de outros nomes, supostos cúmplices, era um dos objetivos da tortura, o que garantia uma autoperpetuação da J ustiça inquisitorial que sempre tinha pessoas a "investigar". Várias eram as espécies de tortura utilizadas, ajustando-se as técnicas aos crimes a serem desvendados. ${ }^{3}$

Depois do tormento eram apresentadas ao réu suas declarações para que ele as ratificasse. Caso não assinasse, seria novamente torturado. Se de novo se recusasse a assinar era considerado diminuto ou negativo, implicando pena de morte. Se aguentasse o fomento sem declarações, o réu era condenado à reclusão, enão "relaxado à justiça secular", eufemismo para a pena de morte.

Toda essa especial ização da tortura garantia a realização de um "processo infalíve" (MANDROU, apud NASPOLINI, 2005, p.196), fazendo do processo inquisitorial a arma perfeita para ser utilizada pela Igreja e pelos Estados ibéricos na perseguição de seus antagonistas.

\subsection{A cusação}

A pós os interrogatórios e as torturas, a fase posterior era

3 "No caso do crime de bruxaria, por acreditar que a bruxa, através de um pacto diabólico, adquiria de Satã o poder de suportar a dor, os juízes utilizavam a tortura da insônia forçada, em que o suspeito era mantido acordado por quarenta horas ou mais, atéque confessasse o crime." (NASPOLINI, p. 196-197) 
a acusação. Ela era feita por um funcionário da Inquisição, o Promotor, que baseavasua peça nos testemunhos enas perguntas feitas ao réu nos interrogatórios. Senão houvesseprovas ou fator concretos, a acusação era baseada nas suposi ções e presunções, invertendo-se a máxima jurídico atual que prega que a dúvida deve beneficiar o réu.

As acusações que pediam a pena de morte, no caso dos negativos e diminutos, terminavam pedindo que o réu fosse castigado "comtodo rigor do di reito eentregueàjustiçasecular". Já a fórmula que pedia outra pena qual quer era "que o réu seja castigado com todo rigor que merece, conforme a di sposição do direito" (SARAIVA, 1985, p. 90).

Constavam no li belo tantas acusações quantas fossem as testemunhas, tal como no interrogatório. Esse expedientenão só permitia que cada fato denunciado fosse explorado ao máximo, de acordo com cada uma das versões apresentadas, como visava impressionar o público quando da leitura da sentença, que se pautava pel as acusações do libelo. A I nquisição além de punitiva, também exercia uma função "educativa" de modo a prevenir futuros delitos.

\subsection{Defesa}

Pode parecer paradoxal, mas é a Inquisição que torna a presença do advogado de defesa figura própria no processo (LOPES, 2000, p. 108). O advogado do réu, no entanto, era nomeado pelo Santo Ofício e trabal hava para ele, devendo ser 
nomeado, quando o Santo Ofício assim julgasse necessário (quando o acusado alegasse inocência, quando houvesse testemunhas de defesa etc.), um advogado honesto, cm experiência em Direito Civil e Canônico, e bastantefervoroso." (EYMERICH, 1993, p. 137).

O advogado tinha de jurar que daria ao acusado uma boa defesa, mas, por outro lado, também devia prestar contas à I nquisição dasuamaneiradeconduzir radefesa, e, eventual mente, denunciar seu cliente (SARAIVA, 1985, p. 92).

A dependência deseu advogado por partedo réu eratotal, uma vez que aquele tinha de escrever e assinar as contraditas às acusações. O poder do advogado, no entanto, era bastante limitado, uma vez que ele não tinha vista do processo e só sabia o queera ao réu comunicado.

Tampouco era permitido ao advogado conversar livremente com seu cliente, sendo essas entrevistas sempre presenciadas por funcionários da Inquisi ção, ou acompanhá-lo às sessões de interrogatórios ou outras di ligências.

Como defender al guém de acusações que não se sabem quais são e nem por que ou por quem foram feitas? Tudo o que se relacionava ao "delito" era dito ao réu de forma vaga, e sua defesa consistia em adivinhar e contestar as denúncias e os denunciantes e procurar provar que tudo aquilo era vingança ou feito por inimigos.

Conhecido o libelo de acusação, o réu se defendia com informações gerais referentes a sua vida como cristão. Depois, o promotor apresentava a "publicação de prova de justiça”, que 
consistia na reprodução dos ditos das testemunhas, e vinham então as contraditas. Nas contraditas, além de adivinhar seus denunciantes e invalidar seu testemunho, era necessário dar nomes de testemunhos que tinham uma série de requisitos para serem aceitas, enquanto que, na acusação, qual quer testemunha era válida. Outra disposição, quanto às testemunhas de defesa, era que se uma tivesse morrido ou desaparecido, não seria comunicado ao réu (SARAIVA, 1985, p. 94-98).

Além do mais, o réu não teria acesso ao despacho das contraditas, a não ser que fossem todas aceitas, para que não soubesse quem eram seus denunciantes.

Salta à vista que a defesa no processo inquisitorial é meramente formal e aparece mais como uma exigência da racionalidade que justifica o processo, do que como uma garantia ao acusado.

\subsection{Sentença e recur so}

Os 13 veredictos possíveis nos processos da I nquisição estão expressos no Manual, indo desde plena absolvição, passando pela abjuração, expiação canônica ea entrega ao braço secular (EYMERICH, 1993, p. 149-181). Também era possível a aplicação de penas pecuniárias (EYMERICH, 1993, p. 234).

As notificações das sentenças eram feitas duas vezes. A primeira, com nova admoestação para que o réu confessasse suas culpas ou o resto delas, e a segunda, no Auto de fé ou pouco antes, nos casos em que o réu era comunicado que estava 
"relaxado ao braço secular". Nesse caso, a notificação era feita antes para que o condenado pudesse preparar sua al ma.

$\mathrm{Na}$ notificação da sentença terminava a jurisdição dos Tribunais Eclesiásticos, já que a I greja não podia tirar a vida de ninguém

Nemtodas as decisõeseramcomunicadasao réu, eaquelas que eles não deveriam ter conheci mento eraminapeláveis, assim como a sentença final.

Os recursos não eram obrigatoriamente aceitos, e ficava ao bel prazer dosinquisi dores a decisão deencaminhar a apel ação para o Consel ho Geral, em especial se o recurso era feito com poucos dias de antecedência do Auto defé

\subsection{Segredo}

Enquanto o processo atual corresob a égi de do princípio da publici dade dos atos processuais, na I nquisição o segredo era a regra institucionalizada.

Da mesma forma que os atos denunciados as pessoas denunciantes não eram informadas ao réu, quase todos os atos eram secretos: os presos juravam segredo a cada interrogatório; os advogados e outros funcionários da Inquisição deviam si lêncio sobre seus atos; a aplicação do tormento não poderia ser divul gada egrande partedas decisões também não eram dadas a conhecer pelo réu e seu advogado antes da sentença. A viol ação desses segredos era crime comparado à heresia, perante o Santo Ofício. 
A té mesmo o Regimento que estruturava o Santo Ofício era secreto e só podia ser lido pelos juízes e promotores, sendo certo que ficava fora do alcance dos advogados, do público e até da mai oria dos funcionários (SARAIVA, 1985, p. 100).

Resumindo: O réu jogava um jogo que ele não sabia as regras, o resul tado durante a partida e, para piorar, o juiz apitava contra. O réu só saberia o resultado final quando terminasse o jogo, mas aí já era tarde e não dava mais para voltar atrás ou tentar reverter o resul tado numa prorrogação.

\subsection{A utos de fé}

As sentenças do Tribunal do Santo Ofício eram lidas e executadas nos autos de fé Podem-se encontrar nesse período autos de fé públicos e "privados". Os últimos eram real izados no palácio da Inquisição ou em conventos e eram normal mente reservados a condenações mais leves, destinados àqueles que eram readmitidos no seio da Igreja. As penas mais comuns eram, então, as penitências espirituais, a prisão e o desterro (SARAIVA, 1985, p. 145).

Osautos defépúblicos eramverdadeirasfestas populares, cheias de pompa e ostentação, realizados normal mente uma vez por ano e compareciam todo o povo, a corte e convidados de honra.

Durante a noite anterior à do culto de fé, os condenados ficavam na capela da Inquisição; de manhã, de volta às celas, vestiamos sambenitos (hábito usado pel os queeram condenados 
pela Inquisição) e eram levados para a procissão.

O evento começava com uma procissão segui da demissa, na qual o sermão tinha um papel todo especial de doutrinação e, por isso, era escol hido al gum membro de destaque do clero.

Depois da missa e do sermão, eram lidas as sentenças, e os condenados à fogueira eram transportados para o lugar do fogareiro. Os que tinham morrido ou fugido durante o processo inquisitorial efossem declarados "relaxados" tinham seus ossos entregues às chamas ou eram queimados "em efígie, para que seus filhos carregassem a marca e a vergonha" (NOVINKY, 1983, p. 67). Vale lembrar que quando a pena aplicada era a de morte, o condenado era entregue à justiça secular, isto é, aos funcionários da Coroa, queo matavam, já quea I greja não podia ser responsável pelo derramamento de sangue.

No entanto, os inquisi dores não aplicavam a pena capital com muita frequência, pois era mais conveniente ter os hereges presos, ou perambulando pelas ruas da cidade, ou confinados nas al deias, para servirem de testemunho da grande e pia obra que realizava a Inquisição. [...] Assim, depois de sair reconciliado com a Igreja, ter seus bens confiscados, o réu passava o resto de sua vida no cárcere ou mendigando pelas ruas. (NOVINSKY, 1983, p. 63-64).

Os autos de fé eram um poderoso instrumento de propaganda do Estado eseus val ores nacionais, pois eramfeitos com o maior ar de festa possível, atraindo a população. Não raro, os autos de fé eram realizados para a celebração de um casamento ou por ocasião de uma visita importante. 


\section{CONSIDERAÇÕES FINAIS}

Apesar de Espanha e Portugal terem desenvolvido, antes da Inquisição, certa unidade nacional (GODINHO apud NOVISNKY, 1983, p. 40), em que os três grupos (cristãos, mouros e judeus) participavam, relacionando-se harmonicamente, interesses econômicos e políticos levaram à quebra desse pacto deconvivência eà expul são e perseguição dos grupos que não se encai xavam mais nas características desejáveis das nações que estavam sendo construídas na península ibérica.

A Inquisição aparece como uma fórmula para enfrentar esseproblema, fazendo comqueosi béricosàépoca dal nquisição Modema vivessem apreensivos, pois não sabiam o que fazer para não cair nas mal has da I nquisição, já que as denúncias não precisavam de nenhuma prova ou indícios concretos para serem feitas, e as prisões imediatamente real izadas. Para piorar, não se sabia como se defender caso fossem pegos pela I nquisição, uma vez que não era informado o acusador, a acusação, nem se escol hia o defensor. Isso os obrigava a tentar seguir exatamente o que o Estado e a I nquisição ibérica apontavam como correto, ou seja, o queera nacional mente desejável.

O Tribunal do Santo Ofício não procuravaa verdadenem os cul pados; buscava vítimas que iriam seguir um caminho já traçado pela I nquisição, que de santa não tinha nada. À procura de dinheiro e manutenção do seu poder, não mediu ações para conseguir o que queria.

Sob a égide da Inquisição, o clero, juntamente com 
OS Estados absolutistas em ascensão, fundamentou suas perseguições ampliando o rol dos cul pávès, engl obando emsuas tipificações, além da criminalidade comum, qualquer oposição que criticasse o saber oficial. Estabeleceu-se uma estrutura ampla e onipresente do poder que não admitia a existência do "outro", do diverso, que era determinado pelo adjetivo herético. (CARVALHO, 2005, p. 203).

Olhando por esse ângulo, o Santo Ofício foi muito eficiente: conseguiu, durante séculos, atingir seus objetivos, por meio da formulação de um direito processual baseado em pressupostos racionais, mas com uma prática completamente irracional, que gozava de grande apoio popular.

É justamente essa fusão aparentemente tão paradoxal que possibilitou que Igreja e Estado, unidos, impusessem uma cultura oficial nacional, instituindo critérios para participação da nação e, consequentemente, do Estado.

Percebese, então, a importância dessa instituição e do processo inquisitorial na consolidação não só do Estado, mas também das nações portuguesa e espanhola. 


\section{REFERÊNCIAS BIBLIOGRÁFICAS}

ANDERSON, Benedict Nação e consciência nacional. São Paulo: Ática, 1989.

BAUMAN, Zygmunt. 0 mal-estar da pós-modernidade. Rio de Janeiro: Jorge Zahar, 1998.

BOFF, Leonardo. Inquisição: um espírito que continua a existir (prefácio). In: EYMERICH, Nicolau. Manual dos inquisidores. 2. ed. Brasília, DF: Rosa dos Ventos, 1993. p. 9-28.

CARVALHO, Salo de. Da desconstrução do modelo jurídico inquisitorial. In: WOLKMER, Antônio Carlos (Org.). Fundamentos de História do Direito. 3. ed. rev. e atual. Belo Horizonte: Del Rey, 2005. p. 201-220.

EYMERICH, Nicolau. M anual dosinquisidores. 2. ed. Brasília, DF: Rosa dos Ventos, 1993.

GROSSI, Paolo. Mitologias jurídicas da Modernidade. Florianópolis: Fundação Boiteux, 2004.

HABERMAS, Jürgen. 0 Estado-nação europeu frente aos desafios da globalização. Novos Estudos. n.43. São Paulo: CEBRAP, novembro 1995. 
HERCULANO, Alexandre. História da origem e estabelecimento da Inquisição em Portugal. 8. ed. Lisboa: Aillaud e Bertrand, [19--]. Tomo 1.

HESPANHA, António Manuel. 0 Direito dos letrados no império português. Florianópolis: Fundação Boiteux, 2006.

LEVACK, Brian P. A caça às bruxas. Rio de J aneiro: Campus, 1988.

LOPES, J osé Reinal do. 0 Direito na H istória. São Paulo: Max Limonad, 2000.

NASPOLINI, 2005, Samyra Haydêe. Aspectos históricos, políticos e legais da Inquisição. In: WOLKMER, Antônio Carlos (Org.). Fundamentos de História do Direito. 3. ed. rev. e atual. Belo Horizonte: Del Rey, 2005. p. 187-200.

NOGUEIRA, Carlos Frederico Coelho. A Inquisição em Portugal. Disponível em 〈http://maxpages.com/cobm/A_ Inquisicao_em_Portugal $>$. Acesso em: 01 abr. 2006.

NOVINSKY, Anita Waingort. A Inquisição. 2. ed. São Paulo: Brasiliense, 1983.

SARAIVA, Antônio J osé A Inquisição e cristãos novos. 5. ed. Lisboa: Estampa, 1985. 
SARAIVA, J osé Hermano. História concisa de Portugal. 16 ed. [Lisboa]: Publicações Europa-América, 1993.

SÉRGIO, Antônio. Breve Interpretação da história de Portugal. Lisboa: Livraria Sá da Costa, 1977. 